\title{
NEUTRALNOŚć MOtDAWII: UWARUNKOWANIA WEWNĘTRZNE I MIĘDZYNARODOWE
}

\author{
NeUtRALITY OF MOLDOVA: \\ ITS INTERNAL AND INTERNATIONAL DETERMINANTS
}

Maciej Herbut*
Renata Kunert-Milcarz

\begin{abstract}
Abstrakt
Neutralność w Mołdawii traktowana jest przez władze państwa jako strategia, która mogłaby zagwarantować przetrwanie $\mathrm{w}$ środowisku międzynarodowym. Niemniej, mimo osadzenia w prawie państwowym (w ustawie zasadniczej), Mołdawia nie posiada gwarancji międzynarodowych dla swojego statusu neutralności, co wynika przede wszystkim z niekonsekwentnej polityki zagranicznej. Mołdawia stoi przed wyborem dwóch strategii: pierwszej, polegające na zacieśnieniu relacji z Zachodem; drugiej, na polepszeniu relacji z Rosją i mimo, że wybór każdej ze ścieżek wiązałby się z wysokim ryzykiem, wydają się one lepsze od polityki
\end{abstract}

\begin{abstract}
Neutrality in Moldova is treated by the state authorities as a strategy that could guarantee survival in the international environment. Despite being referred to even in the country's constitution, Moldova's neutrality is a state not recognized by the international community, which is mostly due to an inconsistent foreign policy. Under such circumstances, Moldova is torn between two strategies: the betterment of the relationship with Russia, or tightening the cooperation with the West. Both strategies are problematic, yet they seem more adequate than the strategy of inconsistent neutrality pursued thus far.
\end{abstract}

* Instytut Politologii, Uniwersytet Wrocławski (maciej.herbut@uwr.edu.pl); orcid.org/0000-0001-6993-5857.

iD https://

** Instytut Studiów Miedzynarodowych, Uniwersytet Wrocławski (renata.kunert-milcarz@ uwr.edu.pl) iD https://orcid.org/0000-0002-1582-9511. 
pozorowanej neutralności, jaką państwo to dotychczas prowadziło.

Słowa kluczowe: Republika Mołdawii, neutralność, polityka zagraniczna, Rosja
Key words: Republic of Moldova, neutrality, foreign policy, Russia

\section{Wstęp}

Celem postawionym w niniejszym artykule jest zaprezentowanie fenomenu polityki neutralności i jej uwarunkowań na przykładzie Mołdawii. Ponieważ państwa neutralne mogą prowadzić w miarę niezależną i nieskrępowaną sojuszami politykę zagraniczną, neutralność może przynieść korzyści zarówno polityczne, jak i ekonomiczne (Browning, 2007, s. 34; Niemi, 2014). Są jednak pewne warunki, które muszą zostać spełnione, aby strategia ta okazała się opłacalna (Karsh, 1988, s. 33). Po pierwsze, państwo takie powinno dysponować potencjałem odstraszania (deterrence) w wypadku naruszenia jego suwerenności ${ }^{1}$. Po drugie, neutralność musi być strategią przemyślaną i wynikającą z pewnych determinantów zarówno wewnątrzpaństwowych (stabilność polityczna czy integralność terytorialna i tożsamościowa), jak i międzynarodowych (sprzyjające środowisko międzynarodowe).

Władze w Kiszyniowie traktują neutralność, zapisaną w art. 11 konstytucji z 1994 roku, jako strategię gwarantującą przetrwanie na arenie międzynarodowej (Konstytucja Mołdawii sekcja 1 art. 11). W jakim stopniu jednak status mołdawskiej neutralności jest gwarantem suwerenności — to kwestia sporna. Z tego założenia wynika główna teza badawcza, która wyraża się przekonaniem, że wypracowane $\mathrm{w}$ połowie lat dziewięćdziesiątych XX wieku rozwiązania dotyczące statusu Mołdawii nie odpowiadają współczesnym wyzwaniom i istnieje potrzeba ich redefinicji. Niestabilność polityczna, problemy tożsamościowe państwa, które mają bezpośrednie przełożenie na niespójną, chaotyczną politykę zagraniczną, a także brak integralności terytorialnej oraz asymetryczny charakter relacji z Rosją, która uznaje region poradziecki za wyłączną strefę swoich wpływów, należą do głównych problemów, z którymi państwo musi się zmierzyć. Metody badawcze, wykorzystane w opracowaniu, to głównie analiza komparatystyczna oraz desk research.

${ }^{1}$ Efraim Karsh (1988, s. 33) odnosi się do komponentów: „pozytywnego” i „,negatywnego”. Autorzy artykułu uznali jednak, że użycie sformułowań ,aktywne” i ,pasywne” będzie bardziej adekwatne. Karsh (1988) za komponent ,pasywny” uznaje głównie środki militarne. Autorzy niniejszego artykułu rozszerzają to pojęcie także na gwarancje konstytucyjne i prawnomiędzynarodowe. 
Opracowanie składa się dwóch części: teoretycznej i empirycznej. W części pierwszej poruszony zostanie problem statusu państw neutralnych w stosunkach międzynarodowych. Następnie uwaga zostanie poświęcona dwóm „komponentom", które zdaniem Efraima Karsha w sposób znaczący wpływają na skuteczność polityki zagranicznej państw neutralnych. Podczas gdy komponent „pasywny" odnosi się przede wszystkim do gwarancji prawnomiędzynarodowych oraz militarnych, które są niezbędne do przetrwania państwa, komponent ,aktywny” dotyczy „,charakteru” polityki zagranicznej, która musi być polityką konsekwentną i odpowiadającą wymaganiom środowiska międzynarodowego. Ponieważ państwa neutralne muszą głównie polegać na własnych zasobach (strategia self-help), wymienione elementy są kluczowe dla ich przetrwania². W części drugiej - empirycznej - zostaną przedstawione konstytucyjno-prawne aspekty mołdawskiej neutralności oraz poruszony zostanie problem, jak dalece obrana przez Mołdawię polityka zagraniczna wpisuje się w obecne realia geopolityczne.

Pozycję państwa można rozumieć jako pewien stan wynikający z uwarunkowań zarówno materialnych, jak i relacjonalnych ${ }^{3}$. Jednym z najważniejszych indykatorów statusu państwa jest jego wielkość (Argyle, 1952). Najczęściej wykorzystywanymi wyznacznikami wielkości państw współczesnych są: powierzchnia i zasobność surowcowa, zdolności militarne oraz potencjał społecz$n y^{4}$. W zależności od wielkości można dokonać wstępnej analizy statusu państwa i tego, w jakim stopniu polityka neutralności może przynieść mu korzyści. We współczesnych stosunkach międzynarodowych neutralność stanowi głównie domenę państw małych, które z racji swoich ograniczonych zasobów starają się w sposób optymalny dostosować do swojego środowiska międzynarodowego. Ponieważ państwa małe są szczególnie narażone na naciski z zewnątrz, neutralność, oparta na dobrych relacjach z sąsiadami, może okazać się najskuteczniejszą strategią gwarantującą im przetrwanie (Stokke, 2012, s. 211; Herbut, 2017b).

${ }^{2}$ Państwa neutralne, takie jak Szwecja, Szwajcaria czy Austria, opierają strategię neutralności na komponencie ,,pasywnym”: neutralności zbrojnej w przypadku Szwecji i neutralności uregulowanej przez prawo państwowe w przypadku Austrii oraz Szwajcarii (Chang, 2017; Czarny, 2018, s. 157-162; Konstytucja Austrii rozdz. 1. art. 9a). Są jednak państwa, jak np. Finlandia, które swoją strategię opierają głównie na konsekwentnej i wyważonej polityce zagranicznej (komponent ,aktywny”) (Karsh, 1988, s. 138).

3 Alexander Wendt (1999) w odniesieniu do stosunków międzynarodowych wprowadził rozróżnienie pomiędzy neorealizmem, który jest oparty na materialnych przesłankach (materialist), oraz konstruktywizmem, opartym na relacjonalnych przesłankach (relational).

4 Temat wielkości państw był niejednokrotnie poruszany w literaturze stosunków międzynarodowych. Przykładowo Michael Handel (1990, s. 11-54) za „wyznaczniki” wielkości uznał m.in.: terytorium (area); zasobność w surowce naturalne (natural resources); populację (population). Maurice A. East (1973) z kolei wymienia następujące wyznaczniki wielkości: powierzchnia (land area); populacja (total population); dochód narodowy (total GNP); potencjał militarny (military capabilities). Wielkością państwa zajmowali się także badacze, jak: James Rosenau (2006), Ronald P. Barston (1973), Przemysław Grudziński (2008), Teresa Łoś-Nowak (2011). 
Odnośnie do samego pojęcia neutralności w stosunkach międzynarodowych, to wywodzi się ono od łacińskiego słowa neuter (żaden z dwóch), które oznacza obojętność czy bezstronność państwa ${ }^{5}$ Kategoria neutralności sięga czasów starożytnych, jak ilustruje to historia wojny peloponeskiej Thucydidesa (Kulesza, 2006, s. 28 i in.). Pierwszy raz społeczność międzynarodowa uznała neutralność Szwajcarii na podstawie traktatu pokojowego z Paryża z 1814 roku. Została ona potwierdzona także mocą decyzji kongresu wiedeńskiego z 1815 roku, traktatu wersalskiego z 1919 roku i konstytucji szwajcarskiej z 1874 roku (już w 1813 r., po klęsce Napoleona pod Lipskiem, status neutralności Szwajcarii został potwierdzony przez Zgromadzenie Związkowe; zob. Karsh, 1988, s. 25; Barcik, 2009; Porębski, 2010, s. 51). Kolejnymi państwami europejskimi, które uzyskały podobny status, były Belgia (1839) oraz Luksemburg (1867) ${ }^{6}$. Bardziej współczesnym przykładem neutralności jest Austria, która finalnie potwierdziła swój status w 1955 roku (Kunz, 1956; Karsh, 1988, s. 148-149; Niemi, 2014)7.

Wymienione uprzednio historyczne typy neutralności należy określić mianem neutralizacji ${ }^{8}$. Proces ten cechuje to, że jest on wynikiem działań multilateralnych. Państwa silniejsze, w ramach umów prawnomiędzynarodowych, godzą się na respektowanie neutralnego statusu państwa mniejszego. Ponieważ neutralizacja jest manifestacją interesów mocarstw, za komponent „pasywny”, będący gwarantem neutralności, można uznać prawo międzynarodowe i potencjał militarny państw, którym zależy na utrzymaniu danego status quo. Stanisław Bieleń (2010, s. 68) nie bez powodu sytuuje politykę neutralności w katalogu rozwiązań multilateralnych. Klasyczną neutralność, która przyjmowała charakter neutralizacji, można więc uznać za status łączący się z nieuczestniczeniem w wojnach i niezgodą na stacjonowanie sił zbrojnych na terytorium danego państwa. Co ważne, każde z państw neutralnych ma jednak prawo obrony swojego statusu, w związku z czym może posiadać własną armię i jej używać w sytuacji zagrożenia bezpieczeństwa (Kotliński, 2009, s. 146). Neutralizację można więc uznać za odmianą neutralności, de jure bowiem posiada ona odzwierciedlenie w prawie międzynarodowym i państwowym, i jest strategią mającą na celu przetrwanie państwa. Ta odmiana neutralności może przyjąć charakter neutralności wieczystej, permanentnej czy też stałej (Czarny, 2018, s. 8) ${ }^{9}$.

${ }^{5}$ Ciekawe rozważania natury teoretycznej dotyczące neutralności przedstawiły: Christine Agius i Karen Devine (2011).

${ }^{6}$ Zob. więcej na temat neutralności Belgii: William E. Lingelbach (1933), i Luksemburga: Benoît Majerus and Charel Roemer (2015).

${ }^{7}$ Konstytucja Austrii. Cz. 1. art. 9a.

${ }^{8}$ Neutralizacji nie należy mylić z pojęciem neutralizmu, które w prawie międzynarodowym jest ściśle związane z koncepcją niezaangażowania z czasów zimnowojennych. Zob. więcej: Karsh (1988, s. 28); Encyclopedia Britannica; Arkadiusz Kotliński (2009, s. 145).

9 Zob. więcej na temat państw, które przyjęły wieczystą neutralność: Hans-Peter Neuhold (1982). 
Mimo że neutralizacja ma charakter multilateralny, państwo może także ogłosić neutralność na podstawie działań unilateralnych. Ryszard Czarny określa takie działanie mianem neutralizmu, czyli polityki, która nie jest osadzona w aktach normatywnych (Czarny, 2018, s. 10). Ponieważ decyzja o przyjęciu neutralności jest podjęta przez władze danego państwa, bez ingerencji mocarstw, istnieje ryzyko, że społeczność międzynarodowa nie będzie jej respektować. W takiej sytuacji decyzja o przyjęciu strategii neutralności może mieć daleko idące konsekwencje, w szczególności dla państwa małego, które nie będzie w stanie stawić czoła agresji ze strony silniejszych sąsiadów. Może zatem dojść do rozbieżności między stanem prawnym (de jure) i rzeczywistym (de facto) (Beyer, Hoffman, 2013, s. 292; Herbut, 2017b, s. 177).

Jeżeli mamy do czynienia z neutralnością, która nie posiada gwarancji traktatowych albo istnieje ryzyko jej nierespektowania, państwo ma do wyboru dwa rozwiązania: może polegać na własnych zasobach przy obronie swojej suwerenności (strategia self-help) lub może starać się wypracować pozytywny wizerunek poprzez prowadzenie aktywnej polityki zagranicznej, dzięki której wzmocni swój status (strategia transcending) ${ }^{10}$. Mimo że współczesne państwa neutralne starają się oprzeć swój status na obu strategiach, zazwyczaj jedna z nich okazuje się dominującą. Przykładowo, nie bez powodu neutralność Szwecji określa się mianem neutralności zbrojnej (armed neutrality). Dla tego państwa komponent „pasywny” pod postacią sił zbrojnych i odstraszania potencjalnych agresorów stanowi gwarant jej suwerenności (Karsh, 1988, s. 16; Sundelius, 1990; Niemi, 2014, s. 7). Z kolei innym przykładem jest Finlandia, która w roku 1948 podpisała z ZSRR traktat obronny, na mocy którego oba państwa zadeklarowały wzajemną pomoc w razie agresji z zewnątrz (Kekkonen, 1970; Maude, 1976, s. 12; Browning, 2002, s. 59). Należy jednak podkreślić, że sojusz ten był jedynie środkiem do celu. Juho Kusti Paasikivi, ówczesny premier, uznawał bowiem gwarancje dla ZSRR za kluczowy element fińskiej niepodległości ${ }^{11}$. Dla Finlandii „komponent pozytywny”, oparty na wyważonej polityce zagranicznej, stanowił więc fundament jej neutralności (Karsh, 1986, s. 267). W takim przypadku oba komponenty (,pasywny” i ,aktywny”) ulegają rozmyciu i przetrwanie państwa uzależnione jest od kompetencji jego korpusu dyplomatycz-

${ }^{10}$ Zdaniem Kennetha Waltza (1979, s. 105) wraz ze wzrostem specjalizacji państwa są coraz bardziej od siebie zależne. Zasada samopomocy oznacza, że państwo, mimo korzyści płynących ze specjalizacji, najwięcej uwagi i środków poświęca na zaspokajanie własnych potrzeb i jednocześnie nie uzależnia się od innych państw. Transcending z kolei, zdaniem Paula Shroedera (1994, s. 117), oznacza próbę wykraczania poza zwykłe granice „kolizyjnej” polityki zagranicznej i próbę budowy pozytywnego wizerunku w stosunkach międzynarodowych.

${ }^{11}$ Fiński minister ds. obrony Juri Jukka Häkämies podczas przemówienia w Waszyngtonie w 2007 r. stwierdził, że dla Finlandii istnieją trzy najważniejsze wyzwania geopolityczne: Rosja, Rosja i jeszcze raz Rosja (Kangas, 2011, s. 41). Więcej też na temat zob.: V.K. Vinayaraj (2011, s. 273). 
nego i charakteru polityki zagranicznej ${ }^{12}$. W Europie mamy więc do czynienia z różnymi odmianami neutralności. Podczas gdy neutralność austriacka i szwajcarska jest najbliższa modelowi klasycznemu neutralności-neutralizacji i oparta jest na gwarancjach prawnomiędzynarodowych (de jure), neutralność nordycką należy uznać za odmianę neutralności politycznej (de facto), którą także określa się mianem neutralizmu (Browning, 2007; Czarny, 2018, s. 10). Mimo dominacji jednego z komponentów (pasywnego lub aktywnego) państwa neutralne starają się jednak oprzeć strategię neutralności na obu ogniwach. W przypadku Szwecji, oprócz znaczących inwestycji w przemysł zbrojeniowy, państwo skutecznie wykorzystuje w stosunkach międzynarodowych swoją markę, którą stała się aktywna polityka zagraniczna ${ }^{13}$. Neutralność austriacka nie bazuje tylko na komponencie „pasywnym”, ale także na aktywnej polityce zagranicznej (Mueller, 2011; Brix, 2016; Luif, 2016). Z kolei Szwajcaria, której neutralność jest regulowana prawem międzynarodowym, podobnie jak Szwecja, stara się podeprzeć swój status nie tylko inwestycjami w przemysł zbrojeniowy, ale także budowaniem pozytywnego wizerunku na arenie międzynarodowej (soft power) (Karlsson, 1995; Chang, 2017; Czarny, 2018, s. 157-162).

Mimo wielu różnic istnieją elementy wspólne dla europejskich państw neutralnych. Po pierwsze, wszystkie wymienione państwa wykazują wysoki poziom wrażliwości na swoje najbliższe otoczenie międzynarodowe i są w stanie w sposób adekwatny wykorzystać własne ogrniczone zasoby w celu dostosowania się do istniejącego status quo. Jak zauważyli Dariusz Popławski (2013, s. 21-22), Peter J. Katzenstein (1985) czy Miriam Fendius Elman (1995), nawet subtelne zmiany w środowisku międzynarodowym mogą mieć decydujący wpływ na funkcjonowanie małych państw neutralnych. Ich polityka zagraniczna musi więc być przemyślana, ponieważ konsekwencje błędów mogą okazać się bardziej kosztowne niż w przypadku państw większych (Jervis, 1978, s. 173174; Karsh, 1988, s. 108; Elman, 1995, s. 176; Rutkowski, 2018, s. 28).

Po drugie, neutralne państwa europejskie są aktywnymi i szanowanymi „obywatelami społeczności międzynarodowej”, co jest ściśle związane ze strategią transcending, czyli wykraczania poza zwykłe granice polityki kolizyjnej i podejmowania roli aktywnej strony ${ }^{14}$. Strategia ta jest czymś więcej niż tylko nieangażowaniem się $\mathrm{w}$ sojusze i przyłączaniem się do istniejących bloków politycznych i jest tożsama z odgrywaniem aktywnej roli w stosunkach międzynarodowych (Shroeder, 1994, s. 117; Tunander, 2008, s. 169; Vinayaraj,

12 Karsh (1988, s. 138) w przypadku Finlandii mówi o komponencie „pasywno-aktywnym" (active-passive road to neutrality).

13 O neutralności jak o „marce” pisał Christopher S. Browning (2007).

${ }^{14}$ Pojęcie „dobrego obywatela społeczności międzynarodowej”, które jest ściśle związane ze strategią transcending i odnosi się zdaniem Lee, Chuna, Suha i Thomsena (2015, s. 1-3) do aktywności takich, jak: przeciwdziałanie problemom o charakterze globalnym, nawiązywanie współpracy z innymi państwami i z różnymi organizacjami międzynarodowymi. 
2011, s. 259). Aktywność ta może przejawiać się poprzez: uczestnictwo w organizacjach międzynarodowych; czynne angażowanie się w rozwiązywanie sporów międzynarodowych w charakterze arbitra; promowanie wartości takich, jak prawa człowieka czy ekologia; odgrywanie roli mostu kulturowego czy też gospodarczego. Wszystkie wymienione państwa neutralne z okresu zimnowojennego odgrywały ważne role: Finlandia, którą niektórzy określali mianem pomostu (bridge builder), starała się w sposób pozytywny wpływać na relacje między Wschodem a Zachodem (Hakovirta, 1988, s. 214); Szwecja, Finlandia i Austria były liderami w licznych inicjatywach związanych z ideą rozbrojenia i tworzenia stref bezatomowych ${ }^{15}$. Szwajcaria, która wyspecjalizowała się w mediacjach, wzięła aktywny udział w łagodzeniu konfliktów i kryzysów, jak na przykład w trakcie kryzysu zakładników między USA a Iranem w 1979 roku, podczas negocjacji związanych z zakończeniem wojny wietnamskiej czy też podczas wojny w Algierii w 1962 roku (Hakovirta, 1988, s. 221-223; Schaufelbuehl, Wyss, Bott, 2015). Helsinki, Genewa i Wiedeń stały się „światowymi stolicami”, w których odbywały się liczne konferencje międzynarodowe i w których siedziby miało wiele organizacji międzynarodowych (Hakovirta, 1988, s. 232). Wszystkie wymienione państwa także odgrywały ważną rolę podczas operacji pokojowych w Kosowie (KFOR) czy w Bośni i Hercegowinie (EUFOR) (Andrey, 2010, s. 89). Symbiotyczny charakter strategii transcending i neutralności w sposób znaczący może więc wpłynąć na prestiż i status państw na arenie międzynarodowej (Shroeder, 1994, s. 117; Vinayaraj, 2011, s. 259-260). Co istotne, jest to strategia, która największe korzyści może przynieść państwom małym, które w mniejszym stopniu niż mocarstwa czy państwa średniej wielkości są „obciążane” bagażem ideologicznym czy politycznym ${ }^{16}$. Jak zauważyli Efraim Karsh (1988), Christopher S. Browning (2007, s. 34) czy Johanna Rainio Niemi (2014, s. 8), współczesne państwa neutralne nie prowadzą już polityki

15 Przykładowo, prezydent Finlandii Urho Kekonnen był proponentem utworzenia „,nordyckiej strefy bezatomowej” (Kekkonen, 1970, s. 151-154); Austria z kolei jest państwem, które od początku lat 80 . XX w. podejmuje wszelkie działania zmierzające do wprowadzenia całkowitego zakazu prób z bronią jądrową (Renoldner, 2018, s. 258). Szwecja także aktywnie dążyła do podpisania układu o nierozprzestrzenianiu broni jądrowej z roku 1968 (Quester, 1970).

${ }^{16}$ Ponieważ państwa duże i średnie prowadzą wielowymiarową politykę zagraniczną, muszą one często balansować pomiędzy różnymi opcjami. Współpraca z państwem „a” może więc w sposób negatywny wpłynąć na współpracę z państwem „b”. Co więcej, w przypadku państw silnych gospodarczo i militarnie, to ich „wielkość” wpływa determinująco na ich status. W stosunku do państw dużych i średnich formułowane są często znacznie większe oczekiwania niż w przypadku państw mniejszych. Ponadto, sam potencjał militarny państw dużych, nawet bez istnienia racjonalnych przesłanek, może prowadzić do „dylematu bezpieczeństwa” (Hertz, 1950, s. 158-160). Państwa małe, z kolei, nie tylko nie przyciągają uwagi jak państwa większe, ale często, właśnie z uwagi na swoją „,małość” są bardziej atrakcyjnymi i wiarygodnymi partnerami. Nie mają więc bagażu ideologicznego czy politycznego państw większych. O sile państw małych pisze m.in. Wayne A. Wilcox (1967). 
izolacjonistycznej. Wprost przeciwnie, starają się otwierać na świat i być aktywnymi jego członkami.

Po trzecie, co stwierdzili Miriam Fendius Elman (1995) i Peter Katzenstein (1985), uwarunkowania wewnętrzne państw neutralnych mają znaczący wpływ na ich status międzynarodowy. Ponieważ strategia neutralności oznacza niewiązanie się deklaracjami sojuszniczymi, państwa te muszą polegać głównie na własnych zasobach w obliczu zagrożenia (wspomniana już strategia self-help). To, że we współczesnych stosunkach międzynarodowych nawet mocarstwa nie mogą sobie pozwolić na otwartą agresję, nie oznacza, że nie dysponują one instrumentami wpływu. Wpływ ten może przybierać różne formy: nacisku ekonomicznego, wojny informacyjnej, szantażu politycznego czy też wojny hybrydowej, łączącej z sobą wszystkie wskazane elementy. Ze względu na fakt, że państwa neutralne nie mogą liczyć na sojuszników, to siła instytucji państwowych, stabilność polityczna i stopień zaufania społecznego do elit politycznych mają kluczowe znaczenie przetrwania tych państw. Niemi (2014, s. 1-4) wyraźnie wskazuje na to, że europejskie państwa neutralne, takie jak Austria, Szwecja czy Finlandia, to przede wszystkim państwa stabilne politycznie.

Reasumując, w globalizującym się i dynamicznie zmieniającym się świecie neutralność jest strategią, która może przynieść wymierne korzyści małym państwom neutralnym. Transcending, dzięki któremu państwa te mogą wzmocnić swój status międzynarodowy i stać się aktywnymi i szanowanymi uczestnikami stosunków międzynarodowych, jest strategią korzystną dla państw neutralnych. Podczas gdy usankcjonowanie neutralności w prawie międzynarodowym czy też oparcie jej na sile wojskowej (neutralność zbrojna) można uznać za gwarancję bezpieczeństwa państw neutralnych, to z uwagi na swoją wielkość państwa te powinny też prowadzić wyważoną i przemyślaną politykę zagraniczną. Oba komponenty, ,pasywny” i ,aktywny”, wzajemnie się warunkują i tworzą fundament polityki zagranicznej opartej na neutralności.

\section{Wewnętrzne i międzynarodowe aspekty mołdawskiej neutralności}

Mołdawia opiera swoją politykę neutralności na gwarancjach konstytucyjnych oraz na polityce zagranicznej, którą (przynajmniej z założenia) ma charakteryzować zbalansowane podejście wobec Rosji i Zachodu. Neutralność Mołdawii można więc uznać za pewnego rodzaju hybrydę neutralności austriackiej oraz fińskiej. Ocena, jak dalece jednak strategia ta jest skuteczna, wymaga głębszej analizy. Autorzy najpierw skupią się na historycznym i konstytucyjnym wymiarze mołdawskiej neutralności, po czym przejdą do analizy jej komponentu ,aktywnego”, czyli studium polityki zagranicznej tego państwa. Głów- 
nym założeniem tej części opracowania jest to, że mimo osadzenia w prawie państwowym (w ustawie zasadniczej) Mołdawia nie posiada gwarancji międzynarodowych swojego statusu neutralności, co wynika przede wszystkim z niekonsekwentnej polityki zagranicznej.

\section{Historyczny, formalnoprawny i konstytucyjny wymiar mołdawskiej neutralności}

Od początku lat dziewięćdziesiątych XX wieku Mołdawia borykała się z problemami wewnętrznymi, które ograniczały możliwości Kiszyniowa do prowadzenia niezależnej polityki zagranicznej opartej na strategii neutralności. Po pierwsze, istotną kwestią okazał się problem integralności wewnętrznej państwa i dążenia separatystyczne dwóch regionów: Gaugazji i Naddniestrza; po drugie, oba regiony stały się obiektem działań Rosji.

27 sierpnia 1991 roku ogłoszona została niepodległość Republiki Mołdawii, a już dzień później uczyniła to samo Naddniestrzańska Mołdawska Socjalistyczna Republika Radziecka (NMSRR), przyjmując nazwę Naddniestrzańskiej Republiki Mołdawskiej (NRM), niemniej jednak nie została ona uznana przez społeczność międzynarodową (Lubicz-Miszewski, 2012, s. 123-124). Dodatkowo, procesy separatystyczne, rozpoczęte przez Rosjan i Ukraińców, stanowiących ponad połowę ludności Naddniestrza ulokowanego po zachodniej stronie Dniestru, spowodowały konflikty z prawobrzeżną częścią państwa, w której mocno pobrzmiewały postawy antyrosyjskie i prorumuńskie (Lubicz-Miszewski, 2012, s. 123). Rosja, pozornie przyjmując rolę stabilizatora sytuacji, dzięki wojnie w Naddniestrzu mogła przeprowadzić rekonesans, by stwierdzić, czy polegając na sprzyjających jej i odpowiednio wyposażonych militarnie siłach, prowokujących konflikt z państwem walczącym z separatyzmem, będzie w stanie przejąć wpływy w regionie (Gil, 2014, s. 149-150). W konsekwencji Mołdawia, bez Naddniestrza, została zdecydowanie osłabiona. Mimo podjętych prób likwidacji NRM państwo przyjęło narzucony przez Rosję układ z 1992 roku. Sytuację komplikują dążenia separatystyczne prawosławnej, tureckojęzycznej grupy etnicznej Gagauzów, zamieszkującej obszary południowej części RM. Warto podkreślić, że żadne $\mathrm{z}$ państw neutralnych $\mathrm{z}$ okresu zimnowojennego nie borykało się z takimi problemami, jak Mołdawia. W pewnym sensie trudną sytuację Finlandii i status okupowanego przez ZSRR portu w Porkalla, w którym Rosja ustanowiła bazę wojskową, można przyrównać do statusu regionów separatystycznych w Mołdawii. Zanim jednak Finlandia zaczęła prowadzić skuteczną politykę zagraniczną, opartą na neutralności, w 1955 roku, dzięki zabiegom dyplomatycznym, władze w Helsinkach odzyskały kontrolę 
nad portem (Maude, 1976, s. 37). Mołdawia jednak do dnia dzisiejszego nie zdołała odzyskać kontroli nad regionami separatystycznymi. Wprawdzie Finlandia musiała sprostać wpływom radzieckim na swoim terytorium, jednak oddziaływanie ZSRR w przypadku Mołdawii było dodatkowo podparte jej dążeniami separatystycznymi, co ma znaczący wpływ na status tego państwa na arenie międzynarodowej.

6 marca 1994 roku przeprowadzono w Mołdawii referendum w kwestii neutralności. Mieszkańcy odpowiadali na następujące pytanie: „Czy opowiadasz się za tym, by Republika Mołdawii rozwijała się jako niepodległe, integralne i niepodzielne państwo $\mathrm{w}$ granicach określonych $\mathrm{w}$ dniu proklamowania suwerenności 23 czerwca 1990 roku, prowadzące neutralną politykę, utrzymujące wzajemnie korzystne stosunki ze wszystkimi krajami świata i gwarantujące wszystkim obywatelom prawa zgodne z normami prawa międzynarodowego?" (OSW, 47/1994, s. 5, cyt. za: Pieńkowski, 2013, s. 161). Twierdząco odpowiedziało $95 \%$ głosujących. Wyniki głosowania uznane zostały za wiążące, w warunkach wysokiej frekwencji 75\%. Była to jednoznaczna informacja wskazująca na budowę własnej państwowości bez Rumunii, która nie uznała mocy prawnej głosowania (OSW 48/1994, s. 5, cyt. za: Pieńkowski, 2013, s. 161). Niezależnie od tego art. 11 Konstytucji Republiki Mołdawii z dnia 29 lipca 1994 roku stanowi, że państwo „proklamuje swoją stałą neutralność” oraz ,nie dopuszcza rozmieszczania na swym obszarze sił zbrojnych innych państw”. Artykuł 142 przedstawia, iż postanowienia dotyczące między innymi ,wieczystej neutralności państwa mogą być zmienione jedynie za zgodą udzieloną w referendum" oraz że ,żadna zmiana nie może być dokonana, jeżeli pociągnęłaby za sobą zniesienie podstawowych praw i wolności obywateli lub gwarancji tychże praw i wolności” (Konstytucja Republiki Mołdawii, 1994). Konstytucja została przyjęta bez powszechnego głosowania w referendum ze względu na konflikt z Rosją, który wybuchł w 1992 roku i na skutek którego obszary znajdujące się po zachodniej stronie rzeki: Nistru, Camenca, Râbniţa, Dubăsari, Grigoriopol, Slobozia, w tym Tyraspol, a także liczne miejscowości na prawym brzegu Dniestru pozostały poza kontrolą władz w Kiszyniowie (Nicu, 2017, s. 134; zob. też: Lubicz-Miszewski, 2012).

Neutralność państwa została także potwierdzona w dokumencie strategicznym „Koncepcja polityki zagranicznej Mołdawii” z 8 lutego 1995 roku, którą określono jako jedną z najistotniejszych reguł polityki zagranicznej. $Z$ tej zasady wynikało postanowienie niewikłania się w konflikty zbrojne; niebrania udziału w politycznych sojuszach obronno-wojskowych czy gospodarczych, mających na celu przygotowanie do wojny; braku zgody na lokalizacje obcych baz wojskowych na swoim terytorium; nieposiadanie, nieprodukowanie ani nietestowanie broni jądrowej. Implementacja stałej polityki neutralności miała zabezpieczyć Mołdawię w sferze bezpieczeństwa zewnętrznego i przyczyniać się, wychodząc od analizy położenia geopolitycznego państwa, do większej stabilności i pokoju 
(Cebotari, 2010, s. 84). Co więcej, zgodnie z doktryną bezpieczeństwa narodowego z 6 czerwca 1995 roku, głównym celem neutralności było zapewnienie bezpieczeństwa wojskowego narodu i państwa oraz zapobieganie wojnom i konfliktom zbrojnym za pomocą prawa międzynarodowego (Cebotari, 2010, s. 84-85). Realizując te założenia, Mołdawia nie akceptuje wojny jako środka do osiągnięcia celów politycznych, poza obroną. Głównym celem jest promowanie polityki zagranicznej, która zapewniłaby jej bezpieczeństwo militarne, bez uszczerbku dla innych państw. Mołdawia nie zezwala na wykorzystywanie swojego terytorium do agresywnych działań przeciwko innym państwom i do rozmieszczania na nim obcych wojsk (z wyjątkiem przypadków określonych w umowach międzynarodowych dotyczących rozmieszczenia kontyngentów sił pokojowych) (Cebotari, 2010, s. 85).

Władze w Kiszyniowie dołożyły wszelkich starań, aby strategia neutralności, podobnie jak to było w przypadku Austrii i Szwajcarii, była mocno osadzona w prawie państwowym. Problemem jednak nie jest wymiar formalnoprawny, a aspekt międzynarodowy, któremu zostanie poświęcona następna część niniejszego artykułu.

\section{Międzynarodowy wymiar mołdawskiej neutralności}

Michael Handel (1990), Wayne A. Wilcox (1967) i Ola Tunander (2008, s. 172) twierdzą, że słabości państw małych można przekształcić w siłę, ponieważ charakteryzują się one często większą zdolnością przystosowywania się do zmieniających się okoliczności, co pozwala im również manewrować, a nawet manipulować systemem politycznym. Oczywiście, wszystko zależy od kontekstu, w jaki uwikłane jest każde państwo, w tym i Mołdawia, i może zależeć od konkretnych okoliczności występujących na arenie międzynarodowej. Lata dziewięćdziesiąte XX wieku oraz początek XXI wieku charakteryzowały się przyjęciem polityki, która łączyła dwie strategie: ukrywania się przed zagrożeniami i opowiadania się po stronie silniejszego państwa. Kolejne lata, uwarunkowane relacjami z Unią Europejską, a także ze Stanami Zjednoczonymi, zapoczątkowały przyjęcie strategii mającej na celu ograniczenie wpływów Rosji i odizolowanie się od nich (Kunert-Milcarz, Russu, 2017; Miarka, 2018, s. 129). Te tendencje umocniły się wraz z powołaniem do życia inicjatywy Partnerstwa Wschodniego w 2009 roku. Trzeba jednak zauważyć, że wejście Mołdawii w struktury Eurazjatyckiej Unii Gospodarczej (EUG) jest mało realne (Mołdawia podpisała z Unią Europejską, w ramach programu Partnerstwa Wschodniego, umowę stowarzyszeniową, w tym jej część gospodarczą o pogłębionych i kompleksowych strefach wolnego handlu DCFTA, która w całości weszła w życie 1 lipca 2016 r., 
a zmodyfikowany program stowarzyszeniowy został zatwierdzony w sierpniu 2017 r.) (Zalecenie Rady Stowarzyszenia UE—Republika Mołdawii Nr 1/2017), gdyż Rosja, jako największy gracz w regionie, wciąż posiada tam duże wpływy. W tym kontekście ważne jest podkreślenie, że o ile średnie lub duże mocarstwa mogą uniknąć błędów dyplomatycznych, o tyle w przypadku mniejszych krajów sposób stosowania ostrożnej dyplomacji uzyskuje znaczenie egzystencjalne, ponieważ błędne kalkulacje mogą mieć istotnie poważniejsze konsekwencje, w tym utratę niepodległości, gdy stanie się przed znacznie potężniejszym sąsiadem (Handel, 1990, s. 36). W takiej sytuacji należy zadać pytanie: W jakim stopniu prowadzona polityka zagraniczna tego małego państwa wpisuje się w ogólną sytuację geopolityczną $\mathrm{w}$ regionie?

Państwa małe, takie jak Mołdawia, Litwa, Gruzja czy Estonia, które uzyskały niepodległość po rozpadzie ZSRR, miały do wyboru dwie strategie: pierwsza, polegająca na szybkiej integracji ze strukturami zachodnimi, takimi jak NATO czy UE (strategia bałtycka), oraz druga, polegająca na prowadzeniu bardziej niezależnej polityki zagranicznej opartej na neutralności. Oba podejścia wiązały się z pewnym ryzykiem związanym z bliskością Rosji. Strategia bałtycka opierała się na szybkim oderwaniu się od Rosji i budowaniu pozytywnych relacji z Zachodem. Głównym jej założeniem było stworzenie wizerunku państwa stabilnego i lojalnego wobec Zachodu oraz szybkie członkostwo w strukturach europejskich. Neutralność natomiast jest strategią, która oznacza prowadzenie bardziej bezstronnej polityki zagranicznej. Należy jednak zadać pytanie: Czy państwo małe, jak Mołdawia, wybierając drugą opcję, jest w ogóle w stanie prowadzić politykę zagraniczną, opartą na neutralności?

Jugosławia w trakcie zimnej wojny mogła skutecznie balansować między Wschodem i Zachodem (Niebuhr, 2018). Turkmenistan i Uzbekistan, podobnie jak Mołdawia, ogłosiły swoją neutralność po rozpadzie ZSRR ${ }^{17}$. Istnieją jednak dwa ważne determinanty, które odróżniają te państwa od Mołdawii. Po pierwsze, Mołdawia to państwo małe — znacznie bardziej podatne na zmiany w otoczeniu międzynarodowym i nie jest w stanie stosować strategii balansowania, jak mogą to robić większe państwa. Po drugie, położenie geopolityczne Mołdawii pomiędzy UE a Rosją, sprawia, że prowadzenie „bezstronnej” polityki zagranicznej, szczególnie w obliczu narastającego konfliktu między stronami, wydaje się bardziej problematyczne. W tej części artykułu autorzy starają się udowodnić, że jeden z głównych problemów mołdawskiej neutralności stanowi nie tylko brak konsekwencji w prowadzeniu polityki zagranicznej, ale także rozbieżność pomiędzy jej stanem deklarowanym a rzeczywistym. Wprawdzie władze w Kiszyniowie deklarują neutralność własnego państwa i zabiegają na arenie międzynarodowej o uznanie statusu neutralności Mołdawii, to jednak

17 Zob. więcej o polityce zagranicznej Uzbekistanu i Turkmenistanu (Pannier, 2015; Defence25, 2017; Aleksey, 2019). 
poszczególne rządy budują bezpieczeństwo Mołdawii, opierając się na różnych strukturach międzynarodowych (jak np. NATO czy UE).

Podczas gdy państwa bałtyckie szybko podjęły decyzję o przystąpieniu do NATO i EU i w sposób konsekwentny dążyły do jej realizacji, władzom w Kiszyniowie brakowało wizji (Kunert-Milcarz, Russu, 2017) ${ }^{18}$. Finlandię, której sytuacja geopolityczna pod wieloma względami przypominała sytuację Mołdawii, cechowała przede wszystkim powściągliwość wobec ZSRR (Faloon 1982, s. 3-5). Ponieważ NATO było przez ZSRR postrzegane jako organizacja z założenia wroga, Finlandia dołożyła wszelkich starań, aby wyraźnie odciąć się od Paktu. Władze w Helsinkach nawet określały NATO jako organizację szkodliwą, która przyczynia się do destabilizacji stosunków międzynarodowych (Browning, 2002, s. 51). Mimo wrogich nastrojów społeczeństwa władzy w Helsinkach udało się $\mathrm{w}$ takim stopniu załagodzić relacje z ZSRR, że państwo to nie tylko zachowało swoją suwerenność, ale mogło także aktywnie współpracować z organizacjami zachodnimi, takimi jak EFTA czy WE ${ }^{19}$. Politykę „finlandyzacji” często określano mianem poddańczej ${ }^{20}$. Autorzy niniejszego artykułu są zdania, że było to podejście pragmatyczne - podyktowane sytuacją geopolityczną, jaka zaistniała po II wojnie światowej. Neutralność z założenia jest strategią nieopowiadania się po żadnej ze stron, wobec tego w obliczu narastających konfliktów między Rosją a Zachodem państwo małe o niewielkim znaczeniu geopolitycznym, takie jak Mołdawia, musi przede wszystkim prowadzić politykę niekonfliktową wobec swojego silniejszego sąsiada. Jednak, pomimo deklarowanej neutralności władze w Kiszyniowie w trakcie rządów ugrupowań proeuropejskich prowadziły wyraźnie antyrosyjską politykę (Kunert-Milcarz, Russu, 2017, s. 144).

Mołdawia niejednokrotnie próbowała wyzwolić się z rosyjskiej strefy wpływów, a pogłębiające się relacje z UE oraz partnerstwo z NATO są tego dowodem. Mimo współpracy z Zachodem Rosji nie udało się przekonać władz w Kiszyniowie do członkostwa w takich strukturach, jak Organizacja Układu o Bezpieczeństwie Zbiorowym (OUBZ) czy Szanghajska Organizacja Współ-

18 (Parliament RM, 1995). Zdaniem wielu ekspertów obu dokumentom z lat 1995 (368-XIII) i 2006 (414-IV), oprócz ogólnikowych deklaracji dot. „zbalansowanego” podejścia w stosunkach międzynarodowych, której gwarantem miała być neutralność, brakowało jasnej wizji polityki zagranicznej.

${ }_{19}$ Kiedy mowa o wrogich nastrojach społecznych, to należy wspomnieć, że władze fińskie w pierwszych latach zimnej wojny, w celu poprawy relacji z ZSRR, stosowały autocenzurę. Zob. więcej: Maude (1976), David Arter (1998); Browning (2002, s. 59); Takashi Inoguchi (2003, s. 121). Paradoksalnie, traktat obronny z ZSRR umożliwił Finlandii prowadzenie polityki aktywnej neutralności. W 1957 r. Finlandia stała się członkiem OEEC, a od 1961 r. podjęła bliską współpracę z EFTA i stała się jej pełnoprawnym członkiem w roku 1986. Związek Radziecki nawet wyraził zgodę na podpisanie umowy o wolnym handlu ze Wspólnotą Europejską (WE) w 1973 r. (Vinayaraj, 2011, s. 273).

20 Zob. więcej: Sirkka L. Järvenpää (1990) albo Arter (1998, s. 39—40). 
pracy (SOW) (Štavljanin, 2013, s. 100-102). Wprawdzie neutralność jest wpisana w konstytucję Mołdawii z 1994 roku (Republika, proklamując neutralność, podkreśliła brak możliwości rozmieszczania sił zbrojnych innych państw na swoim terytorium), jednakże w rzeczywistości status ten jest niezwykle trudny do utrzymania ze względu na niestabilność instytucji państwowych, kryzysy polityczne itp. Geopolityka oraz możliwości gospodarcze państwa powodują, że Mołdawia balansuje między Zachodem a Rosją. W ten sposób może osiągać korzyści ze współpracy z Unią Europejską i wschodnim sąsiadem. Przyjmując podejście realistów, że potęga jest czynnikiem decydującym o zachowaniu pozycji międzynarodowej, małe państwa mają skłonność do równoważenia zachowania, utrzymują status quo na arenie międzynarodowej (Archie, 2018, s. 126). Jednak w przypadku Mołdawii, państwa niestabilnego, polityka neutralności może spowodować, że państwo w pełni narażone zostanie na wpływy kulturowe i polityczne Rosji, w której interesie leży pozostanie Mołdawii poza strukturami NATO, zmiana jej europejskiego kursu oraz ,asymetryczna federalizacja" państwa, czyli rozwiązanie problemu Naddniestrza zgodnie z memorandum Dmitrija Kozaka z 2003 roku, które zaproponowane w formule: Mołdawia, Naddniestrze, Rosja, Ukraina i OBWE, zakładało przeobrażanie struktury państwa w asymetryczną federację i akceptację autonomii Naddniestrza i Gagauzji (Rodkiewicz, współ. Konończuk, 2012, s. 2) ${ }^{21}$. Za każdym razem, kiedy władze w Kiszyniowie podejmują próby pogłębienia współpracy z Zachodem, Rosja stosuje metodę „zaciskającej się pętli”. Metoda ta polega na wykorzystywaniu statusu niezależnych regionów Naddniestrza i Gagauzji (Rodkiewicz, współ. Konończuk, 2012, s. 2). Zaproponowane przez Rosję memorandum było ilustracją sposobu, w jaki Kreml widzi rozwiązanie problemu naddniestrzańskiego. Dokument ten nie tylko dawał Naddniestrzu prawo weta $\mathrm{w}$ stosunku do decyzji związanych z polityką międzynarodową Kiszyniowa, ale także legalizował obecność rosyjskich sił pokojowych (w charakterze gwaranta nowego porozumienia) na terytorium zjednoczonego państwa przez okres co najmniej 20 lat. Z perspektywy Kremla tak przeprowadzona federalizacja Mołdawii gwarantowała zachowanie neutralności tego państwa i realnie blokowała wszelkie próby jego integracji ze strukturami zachodnimi (Całus, 2016, s. 77).

Jak słusznie twierdzi Victor Ciobanu, „nie mając wyraźnie na horyzoncie integracji europejskiej, pozbawiona podstawowych gwarancji bezpieczeństwa narodowego, władza w Kiszyniowie nadal upiera się przy chimerze »neutralności strategicznej« (zachowując wojska rosyjskie na swoim terytorium, w Naddniestrzu) i — w odróżnieniu od Gruzji i Ukrainy — nie ma śmiałości dokonać decydującego kroku w stronę NATO" (Ciobanu, 2013, s. 174). Argumenty o wycofaniu wojsk FR z Naddniestrza okazały się nietrafione, zatem warto zastanowić się nad tym, w jakim stopniu pożyteczne okazuje się prowadzenie polityki

${ }^{21}$ Zob. więcej na temat konfliktu w Naddniestrzu: Lubicz-Miszewski (2012). 
trwałej neutralności. Z kolei, biorąc pod uwagę aspekty geopolityczne, usytuowanie na skrzyżowaniu interesów wielkich mocarstw, Svetlana Cebotari (2010, s. 90) twierdzi, że prowadzenie polityki neutralności może skutecznie zabezpieczyć interesy narodowe Republiki Mołdawii oraz przyczynić się do konsolidacji bezpieczeństwa $\mathrm{w}$ regionie poprzez tworzenie więzi oraz dostosowywanie interesów politycznych i gospodarczych służących dobrobytowi narodu. Trudno się z tym zgodzić, ponieważ dla państw małych, będących w niekorzystnej sytuacji wewnętrznej i geopolitycznej, neutralność może zostać obarczona sporym ryzykiem ze względu na niemożliwość podpisania sojuszy obronnych, zdolnych zabezpieczyć kraj przed potencjalnymi zagrożeniami (Herbut, 2017, s. 180).

Władze Mołdawii nie raz, zasłaniając się statusem neutralności, próbowały także drogą prawną osiągnąć swoje cele. Przykładowo, 2 maja 2017 roku Trybunał Konstytucyjny Mołdawii wydał wyrok w sprawie wykładni art. 11. Interpelacja była inicjatywą przedstawicieli Partii Liberalnej, czyli zwolenników przystąpienia państwa do NATO. Stała neutralność została zachowana, niemniej jednak podkreślono, iż państwo posiada prawo do żądania pomocy wojskowej spoza terytorium kraju w przypadku zagrożenia bezpieczeństwa. W orzeczeniu Trybunału nawiązano też do stacjonowania wojsk rosyjskich we wschodnich częściach Mołdawii. Wojska te zostały uznane za obce oddziały okupacyjne. Decyzja Trybunału spowodowała odrzucenie de facto układu mołdawsko-rosyjskiego z 1992 roku (Nicu 2017, s. 137). Mimo poparcia ONZ (Zgromadzenie Ogólne 23 czerwca 2018 r. przyjęło rezolucję w/s wycofania wojsk FR z Naddniestrza), siły rosyjskie wciąż jednak bazują po zachodniej stronie Dniestru. 19 lipca 2018 roku Parlament Mołdawii przyjął strategię bezpieczeństwa narodowego na lata 2018 - 2021, w której potwierdzono, iż stacjonowanie rosyjskich sił zbrojnych na terytorium państwa traktowane jest jako zagrożenie dla bezpieczeństwa wewnętrznego oraz że ich obecność w Naddniestrzu podważa wewnętrzną integralność terytorialną.

Niebagatelne są problemy wewnętrzne Mołdawii: rozkład instytucji państwowych, powszechna korupcja oraz klientelizm i postępująca oligarchizacja (Rumer, 2017, s. 6). Wzmacnianie władzy i wpływów Partii Demokratycznej (Partidul Democrat din Moldova PDM) na czele z oligarchą Vladem Plahotniucem sprowokowało Rosję do włączenia się w proces zmiany władzy w Mołdawii. Do zmiany tej doszło w czerwcu 2019 roku, kiedy powołano koalicję rządową, złożoną z prorosyjskiej Partii Socjalistów (Partidul Socialiştilor din Republica Moldova PSRM) oraz proeuropejskiego bloku ACUM (Strzelecki, 2019). Od listopada 2019 roku w Mołdawii funkcję premiera sprawowała Maia Sandu, polityczka z ramienia Bloku Wyborczego „Teraz” (Blocul electoral ACUM), którego głównym celem było wprowadzenie Mołdawii do Unii Europejskiej (Radio Free Europe, 15 June 2019; Radio Free Europe, 12 November 2019). 14 listopada 2019 roku blok ACUM został odsunięty od władzy i parlament powołał nowy mniejszościowy gabinet Iona Chicu, wspierany przez Partię 
Socjalistów i Partię Demokratyczną, który w rzeczywistości podporządkowany jest PSRM oraz eurosceptycznemu i prorosyjskiemu prezydentowi Igorowi Dodonowi, który wygrał w pierwszych bezpośrednich wyborach prezydenckich w 2016 roku (zob. Całus, 2019). Dodon promował powrót do tzw. zrównoważonej polityki zagranicznej, w ramach której zapowiedział strategiczne partnerstwo z Rosją, podkreślając, że neutralność jest głównym celem oraz nie ma możliwości, by Mołdawia przystąpiła do jakiegokolwiek bloku wojskowego (Radio Free Europe, 23 January 2017; zob. też: Volovoj, 2017, s. 52-55; Miarka, 2018).

Wspomnianą strategię można określić - jako pewnego rodzaju nową kategorię — „neutralnością wojskową”. 5 września 2019 roku prezydent spotkał się z sekretarzem generalnym NATO Jensem Stoltenbergiem. Dodon podkreślił, że status trwałej neutralności zapisany w Konstytucji i zrównoważona polityka zagraniczna (między Wschodem a Zachodem) pozostają podstawowymi priorytetami (Президентура Республики Молдова 2019). W wywiadzie dla BВC potwierdził, że celem strategicznym jest to, by neutralny status państwa został uznany na arenie międzynarodowej, na poziomie Rady Bezpieczeństwa ONZ (Вендик, 2018), gdzie 25 września 2019 roku podczas 74. sesji Zgromadzenia Ogólnego ONZ domagał się faktycznego uznania i przestrzegania statusu neutralności kraju poprzez uzyskanie międzynarodowych gwarancji ${ }^{22}$ (IPN Press Agency, 2019), jednakże powstrzymał się od żądania wycofania przez Federację Rosyjską sił zbrojnych z Naddniestrza, co wywołało otwartą i mocną krytykę ze strony mołdawskiej opozycji.

To zbalansowane podejście wydaje się bardziej wiarygodne od tego, które prezentowały ugrupowania proeuropejskie, czego wyrazem może być dyplomacja prowadzona przez premiera Chicu (Euractiv, 25 listopada 2019; Gotisan, 2020). Z punktu widzenia Moskwy zapewnienia szefa rządu czy też prezydenta Dodona, z których każdy może w kolejnych wyborach zostać zastąpiony przez polityków z ramienia partii prozachodnich, nie są jednak wystarczające. Dopóki sytuacja polityczna w Mołdawii się nie ustabilizuje, Rosja woli „trzymać rękę na pulsie", a wyprowadzenie wojsk z Naddniestrza wydaje się mało prawdopodobne. Zatem uzyskanie przez Mołdawię statusu państwa neutralnego, a także wszelkie próby dołączenia do organizacji, takich jak na przykład NATO (opcja bałtycka) są obecnie niemożliwe.

Z przedstawionych argumentów można wywnioskować, że mimo deklarowanej neutralności władze w Kiszyniowie de facto prowadziły do roku 2019 politykę, która zmierza do uwolnienia się spod wpływów Moskwy. Relacje z Federacją pozostają nadal niezbędnym elementem równania gospodarczego, politycznego i bezpieczeństwa Mołdawii. Obecność wojsk rosyjskich w Nad-

${ }^{22}$ Co nie niesie z sobą żadnej wartości operacyjnej, jak np. w przypadku Turkmenistanu. Zob. więcej: Wywiad z Vladimirem Socorem, analitykiem z Jamestown Foundation: Ursu (2019). 
dniestrzu godzi nie tylko w suwerenność państwa mołdawskiego, które nie wyraziło zgody na stacjonowanie obcych wojsk na swoim terytorium, ale także podważa jej konstytucyjną neutralność (Całus, 2016, s. 85). Inne, równie ważne instrumenty wpływu związane są z polityką surowcową i dostawą surowców energetycznych, handlem (import produktów rolnych i wina do Rosji) czy z polityką wobec mołdawskich migrantów zarobkowych w FR, których w Rosji jest około 600 tys. (zob. Strzelecki, 2019). Niemniej jednak, jeżeli Mołdawia pragnie prowadzić w miarę niezależną politykę zagraniczną, opartą na neutralności, to przede wszystkim musi zabiegać o względy Rosji, bliskie sąsiedztwo (do niego należy zaliczyć także Mołdawię) uznaje za naturalną jej strefę wpływów (Herbut, 2017a, s. 23-24). W takiej sytuacji wejście Mołdawii do Unii Europejskiej byłoby równoznaczne z utratą kontroli przez Rosję nad tym państwem (Russian Foreign Policy Concept, 2013).

W celu zrozumienia motywów działania Rosji warto na stosunki międzynarodowe spojrzeć oczami neorealisty. Zarówno John Mearsheimer (2001; 2014), jak i Waltz (2000) od lat pisali o tym, że Europa od czasu upadku ZSRR zbytnio poszerzała swoją strefę wpływów (Herbut, Kunert-Milcarz, 2017). Podobnie jak w trakcie zimnej wojny, kiedy plan Marshalla, doktryna Trumana i NATO były instrumentami wojny ekonomicznej i militarnej przeciwko ZSRR, Rosja współcześnie postrzega UE i NATO jako zagrożenie dla własnych żywotnych interesów. Federacja pokazała swoją determinację, gdy prozachodnie władze Ukrainy postanowiły podpisać umowę stowarzyszeniową z Unią Europejską. Polityka Rosji wobec Mołdawii jest więc uzależniona od kierunku polityki zagranicznej prowadzonej przez władze w Kiszyniowie. Zaognione relacje z Rosją nie wpływają też pozytywnie na stosunki Mołdawii z państwami zachodnimi (Gotisan, 2020; Necsutu, 2020). Państwa bałtyckie, mimo asymetrycznych relacji z Rosją, obrały konsekwentny prozachodni kurs w polityce zagranicznej, czego uwieńczeniem stało się najpierw członkostwo w NATO, następnie w UE (Zájedová, 1999-2000; zob. więcej: Paulauskas, 2006). Mołdawii natomiast, przez prowadzenie nieudolnej polityki balansowania, oprócz deklaracji, nie udało się zdobyć większej przychylności Zachodu.

Czy Mołdawia mogłaby starać się zwiększyć swoje znaczenie geopolityczne przez aktywną politykę międzynarodową (komponent ,aktywny”), analogicznie do europejskich państw neutralnych? Mołdawia jest wprawdzie członkiem wielu organizacji międzynarodowych i regionalnych, takich jak WNP (Wspólnota Niepodległych Państw), GUAM (Organizacja na rzecz Demokracji i Rozwoju), Rada Europy czy CEFTA (Środkowoeuropejskie Porozumienie o Wolnym Handlu), jednak główne wysiłki władz w Kiszyniowie są skupione na pogłębianiu integracji z Zachodem (Kunert-Milcarz, Russu, 2017, s. 142; BTI Moldova). Najbardziej jednak kontrowersyjną (w szczególności z punktu widzenia Rosji) jest współpraca z NATO. Mimo że europejskie państwa neutralne brały i dalej biorą aktywny udział w operacjach NATO, w przypadku Mołdawii pogłębiona 
współpraca bez wątpienia wzbudza podejrzliwość Rosji (zob. więcej: NATO, Relations with the Republic of Moldova, 2018). Wobec tego neutralność Mołdawii nie mogłaby oprzeć się na komponencie „aktywnym”, trudno bowiem uznać ją za aktora zaangażowanego na arenie międzynarodowej.

Kluczowym elementem, który w sposób determinujący wpływa na politykę zagraniczną Mołdawii, jest jednak nieprzewidywalność i niestabilność wewnętrzna. Kraj ten posiada słaby system polityczny. Charakterystyczny dla tego małego państwa jest także wysoki poziom korupcji oraz nieefektywne reformy gospodarcze (Puls Biznesu, 2018). Według raportu Transparency International z roku 2019 Mołdawia uzyskała 32 na 100 punktów i jest krajem, który zajmuje 120. miejsce na 180 badanych krajów pod względem transparentności (Transparency International, 2020). Zgodnie z opinią Bartłomieja Zdaniuka, ważnym czynnikiem także wpływającym na politykę międzynarodową Mołdawii jest problem wyboru między dwoma zasadniczymi interpretacjami tożsamości narodowej: prorosyjską i unionistyczną (zob. Zdaniuk, 2016, s. 223-232). Podziały społeczne mają więc bezpośrednie przełożenie na sytuację polityczną w kraju i na brak spójnej wizji polityki zagranicznej państwa, co także ma decydujący wpływ na nieskuteczność polityki neutralności.

\section{Zakończenie i ewaluacja}

Dla Mołdawii, kraju słabego politycznie i gospodarczo, neutralność miała się stać substytutem sił zbrojnych, a zarazem dogodnym sposobem ochrony suwerenności i niepodległości. Państwo to musi przede wszystkim przekonać społeczność międzynarodową do swojej neutralności, co władzom w Kiszyniowie się nie udaje. Mimo deklaracji politycznych zarówno Zachód, jak i Rosja nie są gotowe uznać neutralności państwa. Podczas gdy Moskwa traktuje „neutralność” Mołdawii jako argument przeciwko próbom zacieśniania współpracy z zachodnimi strukturami, takimi jak NATO czy UE, Zachód, odwołując się do koncepcji „neutralności”, dąży do wyparcia sił rosyjskich z Naddniestrza (Popławski, 2013, s. 196-197). Wprawdzie neutralność Mołdawii zapisana jest w konstytucji z 1994 roku, jednak w rzeczywistości brak jej gwarancji międzynarodowych. W przypadku Austrii czy Szwajcarii status tych państw był osadzony w prawie międzynarodowym. Finlandia z kolei, państwo, którego sytuacja geopolityczna wydaje się najbliższa tej, w jakiej znajduje się dzisiejsza Mołdawia, prowadziła niezwykle ostrożną i wyważoną politykę zagraniczną, głównie wobec ZSRR. Jeżeli Mołdawia poważnie rozważa strategię neutralności, to powinna przede wszystkim dążyć do załagodzenia relacji z Rosją. Według Georga Maude’a, paradoksalnie, relacje między Austrią i Finlandią a ZSRR, mimo tarć, zbudowane 
były na wzajemnym zaufaniu, które stało się jednym z głównych filarów ich neutralności (Maude 1976, s. 53; por. też: Kekkonen, 1970; Karsh, 1986; Järvenpää, 1990, s. 125-129).

Należałoby więc zgodzić się ze słowami Dionisa Cenuşă (2019), który twierdzi, że mimo starań władz w Kiszyniowie neutralność Mołdawii jest „tworem sztucznym" (artificial construct) i głównymi tego powodami są niespójność polityki zagranicznej i obecność wojsk rosyjskich na terenie Naddniestrza (Całus, 2016, s. 85; Cenușă, 2019). W tej sytuacji rządzący mają dwa wyjścia: pierwsze, polegające na zacieśnieniu relacji z Zachodem; drugie - na polepszeniu relacji z Rosją. Jak już zaznaczono, opcja pierwsza (bałtycka) wiązałaby się ze wzrostem wiarygodności wobec Zachodu i kontynuacją ambitnych reform wewnętrznych. W tej sytuacji Mołdawia dążyłaby do podniesienia swojego statusu względem NATO i UE, które mogłyby bardziej aktywnie działać na jej rzecz. Takie podejście wymagałoby jednak konkretnych deklaracji i porzucenia strategii neutralności. Dopóki zaś istnieje problem integralności terytorialnej i wojska rosyjskie stacjonują w Naddniestrzu, Zachód nie podejmie żadnych działań mogących prowadzić do otwartego konfliktu z Rosją. Opcja druga (fińska) polegałaby na zainicjowaniu polityki ugodowej wobec Rosji. Obecny rząd oraz prezydent wydają się realizować politykę zgodną z tą drogą. Ponieważ rząd Iona Chicu jest rządem mniejszościowym i ponieważ występuje niemal równy podział pomiędzy opcjami prorosyjską i prozachodnią, trudno przewidzieć, jaki „kurs” obierze polityka zagraniczna Mołdawii po kolejnych wyborach. Zważywszy na interes narodowy, władze w Kiszyniowie powinny podjąć decyzję, którą z tych dwóch strategii przyjąć. Mimo że wybór którejkolwiek ze ścieżek wiązałby się z wysokim ryzykiem, to byłoby to rozwiązanie lepsze niż polityka pozorowanej neutralności, jaką państwo to dotychczas prowadziło.

Państwo neutralne może dążyć do zabezpieczenia swojego statusu na trzy sposoby: przez uzyskanie gwarancji prawnomiędzynarodowych; przez rozbudowę swojego arsenału zbrojeniowego; a także przez prowadzenie aktywnej polityki zagranicznej. Aby jednak to osiągnąć, należy przyjąć, że strategia neutralności powinna być oparta na wysokim poziomie „wrażliwości” na zmiany w bliższym oraz dalszym otoczeniu oraz podbudowana przychylnością społeczności międzynarodowej i stabilną sytuacją wewnętrzną. Mimo że neutralność Mołdawii pod wieloma względami przypomina politykę Austrii oraz Finlandii z czasów zimnej wojny i z założenia ma opierać się na gwarancjach prawnokonstytucyjnych (komponent „pasywny”) oraz na aktywnej i ,zbalansowanej” polityce zagranicznej (komponent ,aktywny”), to, z uwagi na brak konsekwencji w działaniach Kiszyniowa i brak „wrażliwości” na zmiany w otoczeniu międzynarodowym, niestabilność polityczną, społeczną i ekonomiczną oraz brak poparcia społeczności międzynarodowej mołdawska neutralność nie jest osadzona na żadnym z wymienionych komponentów. 


\section{Bibliografia}

Agius C., Devine, K. (2011). Neutrality: A Really Dead Concept? A Reprise. Cooperation and Conflict, vol. 46 (3), s. 265-284.

Andrey, M. (2010). Security Implications of Neutrality: Switzerland in the Partnership for Peace. Framework, vol. 9 (4), s. 83-96.

Argyle, M. (1952). The Concepts of Role and Status. The Sociological Review, a44 (1), s. $39-52$.

Arter, D. (1998). Kekkonen and the ,Dark Age' of Finlandised Politics? Irish Studies in International Affairs, vol. 9, s. 39-49.

Asiryan, A. (2019). New Faces, Old Patterns in Uzbekistan's Foreign Policy. Pobrano z: https://thediplomat.com/2019/08/new-faces-old-patterns-in-uzbekistans-foreign-policy/ (data dostępu: 14.01.2020).

Barcik, J. (2009). Neutralność i polityka neutralności a współpraca w ramach Europejskiej Polityki Bezpieczeństwa i Obrony: casus Austrii, Finlandii, Irlandii, Malty i Szwecji. W: B. Mikołajczyk, J. Nowakowska-Małusecka (red.), Prawo międzynarodowe, europejskie i krajowe - granice i wspólne obszary. Księga jubileuszowa dedykowana Profesor Genowefie Grabowskiej (s. 33-53). Katowice: Wydawnictwo Uniwersytetu Śląskiego.

Barston, R.P. (1973). Introduction. In: R.P. Barston, The Other Powers: Studies in the Foreign Policies of Small States (s. 13-28). London: George Allen \& Unwin Ltd.

Beyer J.L., Hoffman S.C. (2011). Varieties of Neutrality: Norm Revision and Decline. Cooperation and Conflict, vol. 46 (3), s. 285-311.

Bieleń, S. (2010). Polityki bezpieczeństwa państw. Teka Komisji Politologii i Stosunków Międzynarodowych PAN, T. 5, s. 64-92.

Brix, E. (2016). The State of Austrian Foreign and Security Policy in Times of Geopolitical Change. In: G. Bischof, F. Karlhofer (eds.), Austrian Studies Today, (s. 239-247). New Orleans: University of New Orleans Press.

Browning, Ch.S. (2002). Coming Home or Moving Home? 'Westernizing' Narratives in Finnish Foreign Policy and the Reinterpretation of Past Identities. Cooperation and Conflict: Journal of the Nordic International Studies Association, vol. 37 (1), s. 47-72.

Browning, Ch.S. (2007). Branding Nordicity: Models Identity and the Decline of Exceptionalism. Cooperation and Conflict: Journal of the Nordic International Studies Association, vol. 42 (1), s. $27-51$.

Całus, K. (2016). Państwo niedokończone. 25 lat mołdawskiej niepodległości. PRACE OSW, 12, Pobrano z: https://www.osw.waw.pl/sites/default/files/prace_59_pl_25_lat_moldaw skiej_net.pdf (data dostępu: 7.0.2020).

Całus, K. (2019). Mołdawia: rząd prorosyjskich socjalistów. Analizy OSW. Pobrano z: https:// www.osw.waw.pl/pl/publikacje/analizy/2019-11-14/moldawia-rzad-prorosyjskich-socja listow (data dostępu: 7.02.2020).

Cebotari, S. (2010). The Republic of Moldova between Neutrality and NATO Memebership Status. Postmodern Openings, vol. 3, s. 83-91.

Cenuşă, D. (2019). International Recognition of Moldova's Neutrality - Lessons to be Learned from Austria and Ukraine, Institute for the Prevention of Hybrid Threats. Pobrano z: https:// h1.md/en/international-recognition-of-moldovas-neutrality-lessons-from-austria-andukraine/ (data dostępu: 14.01.2020).

Chang, F.K. (2017). Sweden's Foreign Policy: Nonaligned, But Not Entirely Neutral.

Geopoliticus, Foreign Policy Research Institutute. Pobrano z: https://www.fpri.org/2017/11/ swedens-foreign-policy-nonaligned-not-entirely-neutral/ (data dostępu: 14.01.2020). 
CIA, Inteligence Report. Finlandization in Action: Helsinki's Experience with Moscow.

Directorate of Intelligence. Sierpień 1972 RSS. No. 0059/72. Pobrano z: http://www.theblackvault.com/documents/esau-55.pdf (data dostępu: 14.01.2020).

Ciobanu, V. (2013). ,Zgubione' państwo pomiędzy Wschodem i Zachodem. W: M. Kosienkowski (red.), Spotkania polsko-mołdawskie. Księga poświęcona pamięci Profesora Janusza Solaka, (s. 169-176). Lublin: Episteme.

Czarny, R.M (2018). Sweden: From Neutrality to International Solidarity. New York: Springer International Publishing.

Defence 24, 2017. Uzbecka neutralność wystawiona na probe. Pobrano z: https://www.defence24.pl/uzbecka-neutralnosc-wystawiona-na-probe (data dostępu: 14.01.2020).

East, M.A. (1973). Size and Foreign Policy Behavior: A Test of Two Models. World Politics, vol. 25 (4), s. $556-576$.

Elman, M.F. (1995). The Foreign Policies of Small States: Challenging Neorealism in its own Backyard. British Journal of Political Science, vol. 25 (2), s. 171-217.

Faloon, V.S. (1982). Aspects of Finnish Neutrality. Irish Studies in International Affairs, vol. 1 , no. 3 , s. $3-12$.

Freedom House (2020). Nations in Transit 2018. Pobrano z: https://freedomhouse.org/sites/ default/files/2020-02/FH_NationsInTransit_Web_PDF_FINAL_2018_03_16.pdf (data do stępu: 14.01.2020).

Gil, A. (2014). Cztery odstony imperium: Rosja - Syberia Zachodnia - Azja Centralna Mołdawia. Lublin: Wydawnictwo Katolickiego Uniwersytetu Lubelskiego.

Gotisan, V. (2020). West Has Lost Patience With Moldova's Pro-Russian Govt, February 11, 2020. Pobrano z: https://balkaninsight.com/2020/02/11/west-has-lost-patience-with-moldovas-pro-russian-govt/ (data dostępu: 22.02.2020).

Grudziński, P. (2008). Państwo inteligentne: Polska w poszukiwaniu międzynarodowej roli. Toruń: Wydawnictwo Adam Marszałek.

Hakovirta, H. (1988). East-West Conflict and European Neutrality. Oxford: Clarendon Press. Handel, M. (1990). Weak States in the International System. London: Frank Cass.

Herbut, M. (2017a). Decoding Russian Foreign Policy Objectives and their Implications for Georgia and Moldova. W: A. Czajowski, R. Kunert-Milcarz, M. Herbut (red.), Georgia and Moldova in the Context of Russian Imperialistic Foreign Policy (s. 21-50). Wroclaw: Wydawnictwo Uniwersytetu Wrocławskiego.

Herbut, M. (2017b). The Application of Role Theory in Explaining the Policies of Small States. W: A. Czajowski, R. Kunert-Milcarz, M. Herbut (red.), Georgia and Moldova in the Context of Russian Imperialistic Foreign Policy (s. 161-186). Wrocław: Wydawnictwo Uniwersytetu Wrocławskiego.

Herbut M., Kunert-Milcarz, R. (2017). The Explanatory Power of Structural Realism in the 21st Century: The Eastern Partnership, Russian Expansionism and the War in Ukraine. Polish Political Science Yearbook, vol. 46 (2), s. 190-204.

Hertz, J.H. (1950). Idealist Internationalism and the Security Dilemma. World Politics, vol. 2 (2), s. $157-180$.

Inoguchi, T. (2003). Political Security: Toward a Broader Conceptualization. International Studies, Vol. 40 (2), s. 105-123. DOI: https://doi.org/10.1177/002088170304000201.

IPN Press Agency. (2019). Igor Dodon Urges from the UN Rostrum to Recognize and Respect Moldova's Neutrality. Pobrano z: https://www.ipn.md/en/igor-dodon-urges-from-theun-rostrum-to-recognize-and-7965_1068413.html\#ixzz6AFugAtDi (data dostępu: 17.01. 2020).

Järvenpää, P.O. (1990). Finland an Image of Continuity in Turbulent Europe. Annals of the American Academy of Political and Social Science, vol. 512 (1), s. 125-139. 
Kangas, A. (2011). Beyond Russophobia: A Practice-based Interpretation of Finnish-Russian/ Soviet Relations. Cooperation and Conflict, vol. 46 (1), s. 40-59.

Karlsson, B. (1995). The Redefining of Swedish Neutrality, 1946-1952. Journal of Peace Research, vol. 32 (1), s. 37-48.

Karsh, E. (1986). Finland: Adaptation and Conflict. International Affairs, vol. 62 (2), s. $265-$ 278.

Karsh, E. (1988). Neutrality and Small States. London and New York: Routledge.

Katzenstein, P. (1985). Small States in World Markets: Industrial Policy in Europe. Ithaca and London: Cornell University Press.

Kekkonen, U. (1970). Neutrality. The Finnish Position. Speeches. Transl. P. Ojansuu. L.E. Keyworth. Ed. T. Vilkuna. London: Heinemann.

Komentarze OSW, nr 74, 18 kwietnia 2012 (s. 2). Pobrano z: https://www.osw.waw.pl/sites/ default/files/komentarze_74_0.pdf (data dostępu: 4.01.2020).

Konstytucja Austrii. Pobrano z: https://www.ris.bka.gv.at/Dokumente/Erv/ERV_1930_1/ ERV_1930_1.pdf. (data dostępu: 4.01.2020).

Konstytucja Mołdawii. Pobrano z: http://www.presedinte.md/titlul1 (data dostępu: 4.01.2020).

Konstytucja Republiki Mołdawii Constituţia Republicii Moldova, (2014). Wstęp i tł. z jęz. rumuńskiego B. Zdaniuk. Warszawa: Wydawnictwo Sejmowe. Pobrano z: https://www. iipvienna.com/new-blog/2018/11/27/austrian-neutrality-as-a-model-for-the-new-easterneurope (data dostępu: 4.01.2020).

Kosienkowski, M. (red.), Spotkania polsko-mołdawskie. Księga poświęcona pamięci Profesora Janusza Solaka (s. 169-177) Lublin: Episteme.

Kotliński, A. (2009). Modele bezpieczeństwa państw. Zeszyty Naukowe Dolnoślaskiej Wyższej Szkoły Przedsiębiorczości i Techniki. Studia z Nauk Społecznych, nr 1, s. 145156.

Kowalicka, M. (2004). Polityka neutralności współcześnie. International Journal of Management and Economics, vol. 15, s. 174-188.

Kulesza, R. (2006). Wojna peloponeska. Warszawa: Wydawnictwo Askon, Wydawnictwo Attyka.

Kunert-Milcarz, R., Russu, V. (2017). Between East and West: The Republic of Moldova under Russian. W: A. Czajowski, R. Kunert-Milcarz, M. Herbut (red.), Georgia and Moldova in the Context of Russian Imperialistic Foreign Policy (s. 137-160). Wrocław: Wydawnictwo Uniwersytetu Wrocławskiego.

Kunz, J.L. (1956). Austria's Permanent Neutrality. The American Journal of International Law, vol. 50, no. 2, s. 418-425.

Lee, S., Chaesung, C., Suh, H., Thomsen, P. (2015). Middle Power in Action: The Evolving Nature of Diplomacy in the Age of Multilateralism, East Asia Institute, EAI Middle Power Diplomacy Initiative (MPDI) Report. Pobrano z: https://www.files.ethz.ch/ isn/191150/30.04.2015.pdf (data dostępu: 18.01.2020).

Lingelbach, W. (1933). Belgian Neutrality: Its Origin and Interpretation. The American Historical Review, vol. 39 (1), s. 48-72. DOI: 10.2307/1839224.

Łoś-Nowak, T. (2011). Polityka zagraniczna: Aktorzy — potencjały — strategie. Warszawa: Wydawnictwo Poltext.

Lubicz-Miszewski, M. (2012). Geneza, przebieg i próby przezwyciężenia konfliktu o Naddniestrze. Zeszyty Naukowe WSOWL, nr 3 (165), s. 121-138.

Luif, P. (2016). Austrian Neutrality in the 21st Century. In: G. Bischof, F. Günter (eds.), Austrian Studies Today. New Orleans: University of New Orleans Press.

Maas, M. (2009). The Elusive Definition of the Small State. International Politics, vol. 46, s. 65 -83. DOI: $10.1057 /$ ip.2008.37. 
Majerus, B., Roemer, C. (2015). Luxemburg, International Encyclopedia of the First World War. Pobrano z: https://encyclopedia.1914-1918-online.net/article/luxembourg (data dostępu: 18.01.2020).

Maude, G. (1976). The Finnish Dilemma: Neutrality in the Shadow of Power. Royal Institute of International Affairs. London: Oxford University Press.

Mearsheimer, J. (2001). The Tragedy of Great Power Politics. New York: W.W. Nonon \& Company Ltd.

Mearsheimer, J. (2014). Why the Ukraine Crisis Is the West's Fault: The Liberal Delusions That Provoked Putin. Foreign Affairs, vol. 93 (5), s. 77-84, 85-89.

Miarka, A. (2018). Stosunki mołdawsko-rosyjskie w drugiej dekadzie XXI wieku. Przeglą Wschodnioeuropejski, T. 9 (1), s. 129-141.

Moldova Forms Pro-Russian Minority Government. Pobrano z: https://www.euractiv.com/section/europe-s-east/news/moldova-forms-pro-russian-minority-government/ (data dostępu: 28.01.2020).

Mueller, W. (2011). A Good Example of Peaceful Coexistence? Pobrano z: http://www.austriaca.at/6898-0 (data dostępu: 18.01.2020).

NATO, Relations with the Republic of Moldova. (2018). Pobrano z: https://www.nato.int/cps/ en/natohq/topics_49727.htm (data dostępu: 15.01.2020).

Necsutu, M. (2020), West Doubts Moldova's Commitment to Reform. Pobrano z: https://iwpr. net/global-voices/west-doubts-moldovas-commitment-reform (data dostępu: 18.01.2020).

Neuhold, H. (1982). Permanent Neutrality in Contemporary International Relations: A Comparative Perspective. Irish Studies in International Affairs, vol. 1 (3), s. 13 -26.

Neutrality. Encyclopaedia Britannica. Pobrano z: https:/www.britannica.com/topic/neutralism (data dostępu: 18.01.2020).

Nicu, D. (2017). Constitutional Vices of the Republic of Moldova. Ante Portas - Studia nad Bezpieczeństwem, T. 1 (8), s. 127-138.

Niebuhr, R. (2018). The Search for a Cold War Legitimacy: Foreign Policy and Tito's Yugoslavia.: Leiden-Boston: Brill, Balkan Studies Library.

Niemi, J.R. (2014). The Ideological Cold War, The Politics of Neutrality in Austria and Finland. New York: Routledge.

Ośrodek Studiów Wschodnich, „Wiadomości”, T. 47 (639), 7 marca 1994, s. 5 (biuletyn wewnętrzny OSW).

Ośrodek Studiów Wschodnich, „Wiadomości”, T. 48 (640), 8 marca 1994, s. 5 (biuletyn wewnętrzny OSW).

Pannier, B. (2015). Revisions To Turkmenistan's Neutrality Policy. Pobrano z: https://www. rferl.org/a/turkmenistan-afghanistan-positive-neutrality-revisions/27301927.html (data dostępu: 18.01.2020).

Parlament RM. (1995). Pobrano z: http://www.parlament.md (data dostępu: 18.01.2020).

Paulauskas, K. (2006). The Baltics: From Nation States to Member States. Pobrano z: https:// www.iss.europa.eu/sites/default/files/EUISSFiles/occ62.pdf. (data dostępu: 11.01.2020).

Pieńkowski, J. (2013). Dlaczego Rumunia zawsze będzie kochać Mołdawię. W: M. Kosienkowski (red.), Spotkania polsko-mołdawskie. Księga poświęcona pamięci Profesora Janusza Solaka (s. 151-169). Lublin: Episteme.

Popławski, D. (2013). Polityka neutralności i bezaliansowości. Warszawa: Scholar.

Porębski, A. (2010). Wielokulturowość Szwajcarii na rozdrożu. Kraków: Wydawnictwo Uniwersytetu Jagiellońskiego.

Prezidentura Respubliki Moldova, Prezident Igor Dodon provel vstreču s General'nym Sekretarem NATO. (2013). Pobrano z: http://presedinte.md/rus/presa/presedintele-igor-dodona-avut-o-intrevedere-cu-secretarul-general-al-nato (data dostępu: 10.01.2020). 
Puls Biznesu za: PAP, (2018). KE krytykuje Mołdawię za słabe postępy w walce z korupcja. Pobrano z: https://www.pb.pl/ke-krytykuje-moldawie-za-slabe-postepy-w-walce-z-korup cja-909796 (data dostępu: 18.01.2020).

Quester, G.H. (1970). Sweden and the Nuclear Non-Proliferation Treaty. Cooperation and Conflict, vol. 5 (1), s. 52-64.

Radio Free Europe, "Moldovan President Says ,Strategic Partnership' with Russia is Essential" (2017). Pobrano z: https://www.rferl.org/a/moldova-dodon-strategic-partnership-rus sia-/28251575.html (data dostępu: 14.01.2020).

Radio Free Europe, Moldovan Government Collapses; EU Calls Development 'Worrying'. (2019). Pobrano z: https://www.rferl.org/a/moldovan-parliament-to-consider-confidencevote-in-sandu-s-cabinet/30265748.html (data dostępu: 18.01.2020).

Radio Free Europe, New Moldovan Government Vows Stronger Ties With EU. (2019). Pobrano z: https://www.rferl.org/a/new-moldovan-government-vows-stronger-ties-with-eu/300 01220.html (data dostępu: 18.01.2020).

Renoldner, K. (2018). Austria and its efforts towards the prohibition of nuclear weapons. Medicine, Conflict and Survival, vol. 34 (4), s. 258-262.

Rodkiewicz, W., Konańczuk, W. (2012). Strategia Rosji w Mołdawii: Kontynuacja czy zmiana? Komentarze OSW, $n r$ 74. Pobrano z: https://www.osw.waw.pl/sites/default/files/ komentarze_74_0.pdf (data dostępu: 11.01.2020).

Rosenau, J. (2006). Pre-theories and Theories of International Politics. In: J. Rosenau (ed.), The Study of World Politics. New York: Routledge.

Rumer, E. (2017). Moldova Between Russia and the West: A Delicate Balance. Pobrano z: https://carnegieendowment.org/files/Rumer_Moldova_Between_Russia_and_the_West2. pdf (data dostępu: 18.01.2020).

Rutkowski, T. (2018). Fenomen „korytarza” terytorialnego w stosunkach międzynarodowych na wybranych przykładach. Fundacja „Dzień Dobry! Kolektyw Kultury” Siemianowice Śląskie.

Schaufelbuehl, J.M., Wyss, M., Bott, S. (2015). Choosing Sides in the Global Cold War: Switzerland, Neutrality, and the Divided States of Korea and Vietnam. The International History Review, vol. 37 (5), s. 1014-1036.

Shroeder, P. (1994). Historical Reality vs. Neo-Realist Theory. International Security, vol. 19 (1), s. $108-148$.

Stokke, K. (2012). Peace-building as Small State Foreign Policy: Norway's Peace Engagement in a Changing International Context. International Studies, vol. 49 (3\&4), s. 207231. DOI: $10.1177 / 0020881714532334$.

Strzelecki, J. (2019). Zmiana rosyjskiej taktyki wobec Mołdawii. Analizy OSW. Pobrano z: https://www.osw.waw.pl/pl/publikacje/analizy/2019-06-25/zmiana-rosyjskiej-taktyki-wo bec-moldawii. (data dostępu: 24.01.2020).

Sundelius, B. (1990). Sweden: Secure Neutrality. The Annals of the American Academy of Political and Social Science, vol. 512, s. 116-124.

Transparency International, Moldova. Pobrano z: https://www.transparency.org/country/ MDA\#v (data dostępu: 18.01.2020).

Tunander, O. (2008). Ola Geopolitics of the North: Geopolitik of the Weak: A Post-Cold War Return to Rudolf Kjellén, Cooperation and Conflict, vol. 43 (2), s. 164-184.

Ursu, V. (2019). Vladimir Sokor: «Dodon vpervye govorit o „,voennom nejtralitete“». Pobrano $\mathrm{z}$ : https://moldova.europalibera.org/а/владимир-сокор-додон-впервые-говорит-о-воен ном-нейтралитете-это-новая-формулировка-/30191380.html (data dostępu: 4.01.2020).

Vendik, Û., Prezident Dodon o nejtralitete Moldovy, partnerstve s Rossiej i balanse s Zapadom, BBC. (2018). Pobrano z: https://www.bbc.com/russian/features-46188800 (data dostępu: 10.01.2020). 
Vinayaraj, V.K. (2011). Finland's Self-defence Strategies. International Studies, vol. 48 (3\&4), s. $257-280$.

Volovoj, V. (2017). How the west lost Moldova to Russia. Ante Portas - Studia nad Bezpieczeństwem, T. 1 (8), s. 47-59.

Waltz, K. (1979). Theory of International Politics. Massachusetts: Addison-Wesley Publishing.

Waltz, K. (2000). Structural Realism after the Cold War. International Security, vol. 25 (1), s. $5-41$.

Wendt, A. (1999). Social Theory of International Relations. New York-Camebridge: Cambridge University Press.

Wilcox, W.A. (1967). The Influence of Small States in a Changing World. The Annals of the American Academy of Political and Social Science, vol. 372, s. 80-92.

Wywiad Tomasza Horbowskiego z Oazu Nantoim, Trudny wybór Mołdawii. ZNAK, nr 720, maj 2015. Pobrano z: http://www.miesiecznik.znak.com.pl/7202015z-oazu-nantoim-rozma wia-tomasz-horbowskitrudny-wybor-moldawii/ (data dostępu: 18.01.2020).

Zájedová, I. (1999-2000). The Baltic States' Security and NATO Enlargement. Perspectives, vol. 13, s. $79-90$.

Zalecenie Rady Stowarzyszenia UE—Republika Mołdawii Nr 1/2017 z dnia 4 sierpnia 2017 r. w sprawie programu stowarzyszeniowego UE—Republika Mołdawii [2017/1489]. Dziennik Urzędowy Unii Europejskiej L 215/3.

Zdaniuk, B. (2016). Konsolidacja państwa w Republice Mołdawii. Warszawa: Wydawnictwo Uniwersytetu Warszawskiego.

Maciej Herbut, dr, adiunkt, pracownik Instytutu Politologii Uniwersytetu Wrocławskiego. Badania naukowe koncentruje na teorii współczesnych stosunków międzynarodowych, polityce zagranicznej państw, filozofii nauki i szeroko pojętej analizie systemowej w naukach społecznych.

Renata Kunert-Milcarz, dr, adiunkt, pracownik Instytutu Studiów Międzynarodowych Uniwersytetu Wrocławskiego. Prowadzi badania naukowe w wymiarze stosunków zewnętrznych Unii Europejskiej z państwami byłego ZSRR oraz badania porównawcze nad demokratyzacją. Zainteresowania badawcze skupia również wokół zagadnień z obszaru psychologii polityki. 